大工)，田坂明政 (同志社工)，八尾伸也（阪大工）

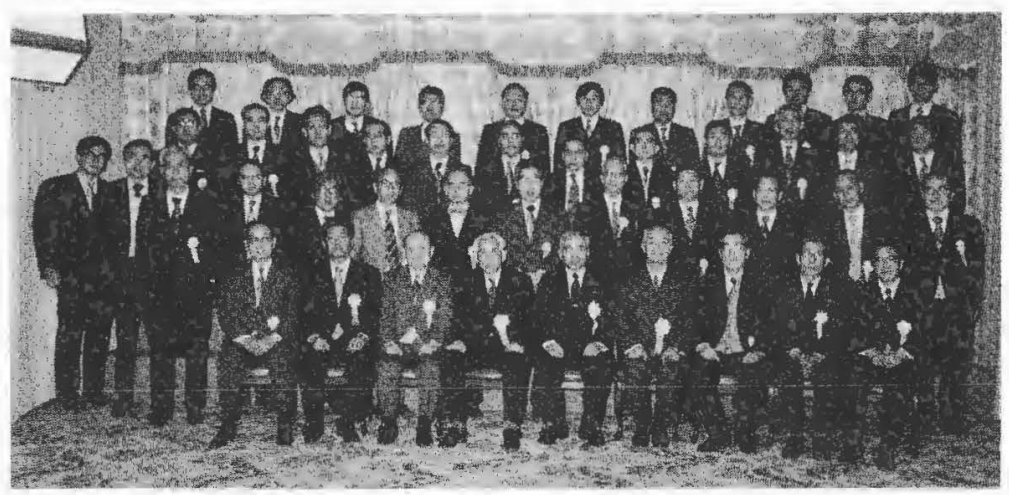

溶融塩委員会創立 20 周年記念

(京都タワーホテル, 昭和 53 年 2 月)

\title{
4. 電子材料委員会
}

\section{1 設 立}

電子材料委員会が設立されたのは昭和 36 年 (1961 年) である。当時の専門委 員会会務事業報告によると, 初代委員長に牧島象二氏 (東大), 幹事に瓜生敏三 氏（信越化学）がそれそれれ就任し，委員には長船広衛氏（日本電気）他そうそ うたる方々 26 名が名を連ねている。後に本会の会長となる向坊 隆氏 (東大) や 安福賁民氏 (富士通信機) の名も見える。当時はトランジスタの発明から既に 十数年が経ち, 日本に扔いても各企業が争って種々の実用化技術を開発してい た。そして, “集積回路”が技術者の話題となってきた時代である。米国の ECS ではこれらの状況を反映して, 半導体技術に関する研究発表が盛んになってい たが，本会でも「ECS の半導体部門に対応して，国内の技術者や研究者の技術 協力の場にしたい意向で電子材料委員会を設立した(長船広衛, 電気化学, 39, $929(1971)) 」 。$ 設立後本年で32年を経過し, その間委員数の増減はあったが, 
常に熱意ある多くの委員の参加を得て,この伝統ある委員会の活動を維持して きた。特に，塚本哲男氏（湖北短大）はをの後の半導体関係の種々の学会の攻 勢にも関わらず，長期に亘り委員長として委員会の運営，維持に多大の努力を 払った。現在の委員数は 18 名である。生た, 委員長は次の変垔を経て現在第 7 代目に至っている。

歴代委員長：牧劰象二 (東大), 昭和 36 年 40 年；小寺嘉秀 (東工試), 昭和 41 年 43 年; 瓜生敏三 (信越化学), 昭和 43 年 46 年; 長船広衛 (日本電 気)，昭和 46 年 $\sim 48$ 年；塚本哲男 (湖北短大)，昭和 48 年 $~ 60$ 年；古川静二 郎 (東工大)，昭和 60 年 $~ 61$ 年；東迎良育 (富士通)，昭和 62 年～現在

\section{2 活 動}

電子材料委員会の活動は委員会設立の翌年 (昭和 37 年) 4 月の講演会開催に 始史る。“電気化学者のための最新の電子材料”と題して，半導体技術，磁気材 料, 強誘電体および光メーザーにわたる講演を日本化学会講堂で行った。電子 材料全般に関するこの種の講演会牥昭和 40 年まで毎年春虫たは夏に開かれた。 昭和 39 年秋にはテーマを半導体に絞った“半導体材料シンポジウム”が電気俱 楽部で開催され，その後定例事業として昭和 46 年の第 6 回開催まで続いた(但 し，昭和 44 年及び 45 年を除く)。また昭和 44 年から 47 年の間は，電子材料分 野が多くの専門分野に跨がる境界領域に関放ることから，“境界領域に敌ける電 気化学請習会”が開かれている。しかし，昭和 46 年以降は，集積回路も実用化 時代に入り，半導体技術が急速に発展する。そのため，本委員会の活動は半導 体プロセス技術を中心をするセミナ一及びシンポジウムの開催に主力を注ぐこ とになる。

昭和 46 年に長船広衛氏 (日本電気) が委員長に就任し，その年の10月に“半 導体・集積回路の生産技術シンポジウム”が開催された。これがその後の本電 子材料委員会活動の柱として定着するものとなる。当時, 集皘回路は世に出て 間もないころであったが,数々の可能性を秘めた技術として技術者のみならず， 情報産業界の大きな関心の的となった。米国では1Kダイナミックメモリーが 出現し，国内各社もその開発に取り組んでいた年である。本シンポジウムの第 
1 回会議の模様について, 長船氏は講演数及び参加者数が予定を大幅に越え, 急遽会場の変更をせざるを得なかったと報告している（長船広衛, 電気化学, 39,929(1971))。以来, 本シンポジウムは東京八重洲のブリヂストンホールを会 場として，年 2 回開催されることが定着し，その後都合により会場を変更する までの約 20 年間ブリヂストンホール・シンポジウムとして親しまれ，今日半導 体分野で指導的立場にある多くの技術者の登竜門としての役割を果たしてき た。但し、シンポジウムの名称は昭和 48 年に“半導体・集積回路技術シンポジ ウム”に変更されている。平成 3 年 7 月には 40 回目の節目を迎え，第 40 回記 念シンポジウムとして特別企画を行った。即ち，この時長年慣れ親しんだ会場 を東京芝の機械振興会館に移し, 歴代委員長の参加を得て招待講演 7 件を含む 盛大な会議を開催することができた。また，本シンポジウムとしては初めて米 国 ECS を代表する 2 名の研究者を招待し，基調講演を依頼した(東迎良育，電 気化学, 59,1017(1991))。本シンポジウムは第 40 回以来の新会場において, 本 年 6 月に第 44 回目を迎える。その間, 半導体技術は LSI, 超 LSI 時代を通り過 ぎ, 当初不可能に思えたULSI を生産する時代を迎えている。従って, 本電子 材料委員会は主として集積回路技術の歷史と共に歩んできたのであり，その発 展に幾らかでも寄与することが出来たことは幸いである。

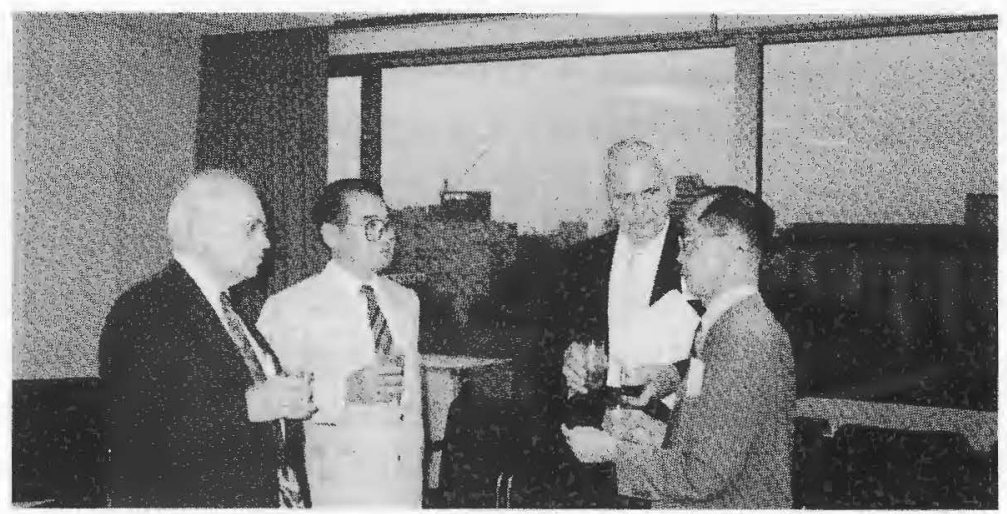

電子材料委員会第 40 回シンポジウム烈親会 (東京・機械振興会館, 平成 3 年 7 月) 
その他に, 本委員会は本協会における殆ど唯一の電子材料分野担当委員会と して，1986 年の日米合同 ECS 会議および本年 5 月に再び開催される同合同会 議には応用物理学会と共同で日本側エレクトロニクスデビジョンを構成し, 会 議の企画・運営に参加した。また, 昭和 57 年以来, 半導体関連の“ドライプロ セスシンポジウム”を応用物理学会と共催している。

（東迎 良育）

\section{5. 溶液化学委員会}

\section{1 設 立}

溶液化学委員会はその前身である「電解質溶液の化学郎談会」の発足（昭和 53 年 $(1978$ 年)) から, 今年で 16 年目を迎える。その間, 昭和 58 年第 6 回 “溶 液化学シンポジウム”を機に,「溶液化学研究会」が発足し, 現在, 会員数約 250 名に至っている。溶液化学委員会と溶液化学研究会は以後, 表裏一体の関係を 保ちつつ, 年 1 回の“溶液化学シンポジウム” の開催を中心に活発な活動を続 けている。この“溶液化学シンポジウム”は電解質溶液に限らず, 広く溶液全 般の諸問題についてのわが国の唯一の研究発表・討論の場となっており，その 活動は国際的にも広く認められ，高く評価されている。

国際的な活動状況の点からみれば, 1960 年代後半から 1970 年代の前半は, 液 体論や溶液論, 特に電解質溶液論においては, Rasaiah-Friedman の“Primitive Model”, Waisman-Lebowitz の電荷剛体球系の $\mathrm{P}-\mathrm{Y}$ 方程式の解析解の発見 など理論的な研究の著しい発展の時期であった。昭和 47 年 8 月 26 日〜 97 日, 京都国際会議場で第 9 回国際結晶学会が開かれ，H. A. Levy 教授の水と $\mathrm{LiCl}$ 水溶液の中性子と $\mathrm{X}$ 線回折の見事な測定結果が報告され, わが国の電解 質を含む液体や溶液の構造化学の研究者に衝撃を与えたのもこの時期であっ た。一方, 国内ではこの様な動向の中で, 昭和 43 年田中信行氏 (東北大理) を 代表とする文部省科学研究費補助金総合研究 (A) (以下単に総合研究 (A) と 記す）「無機イオンの溶存状態に関する研究」が組織され，分析化学や無機·錯 